\title{
Adhesion of Shigella dysenteriae type 1 and Shigella flexneri to guinea-pig colonic epithelial cells in vitro
}

\author{
B. GUHATHAKURTA, D. SASMAL and A. DATTA
}

National Institute of Cholera and Enteric Diseases, Calcutta 700 010, India

\begin{abstract}
Summary. Adhesion of bacteria to guinea-pig colonic epithelial cells in vitro was inhibited by fucose with all the four strains tested (two of Shigella dysenteriae type 1 and two of $S$. flexneri). $\mathrm{N}$-acetyl neuraminic acid and $\mathrm{N}$-acetyl mannosamine also caused inhibition, suggesting a multiplicity of receptors on the epithelial cell. Congo-red binding of the strains correlated with their adhesive ability, whereas haemagglutination of rabbit erythrocytes by the bacteria did not.
\end{abstract}

\section{Introduction}

In shigellosis, bacterial invasion of colonic epithelial cells (CECs) and the production of toxin are the most significant events responsible for the clinical manifestation of the disease. Adhesion of the bacteria to the epithelial cells before internalisation is, therefore, a pre-requisite. Attachment of bacteria to mammalian cells is often mediated through sugar-lectin interaction; and the adhesion molecule may be a haemagglutinin also. We have observed haemagglutination by Shigella dysenteriae type 1 and $S$. flexneri previously. ${ }^{1}$

The objective of this study was to observe adhesion of isolates from patients to guinea-pig CECs in vitro under different conditions, and to investigate surface properties of the bacteria-hydrophobicity, Congored binding and haemagglutination - which may relate to such adhesion.

\section{Materials and methods}

\section{Bacterial strains and growth}

Two isolates of $S$. dysenteriae type 1 (strains 1609 and PB60) and two of S. flexneri (strains IDBM330 and ND22) from clinical cases of human shigellosis were grown for $18 \mathrm{~h}$ at $37^{\circ} \mathrm{C}$ in colonising factor $(\mathrm{CF})$ broth or on CF agar. $^{2}$

\section{Haemagglutination}

Bacteria grown on CF agar were suspended in Trisbuffered Krebs Ringer (KRT) solution ${ }^{3}$ at a con-

Received 13 June 1991; accepted 21 Aug. 1991 centration of $c \cdot 10^{11} \mathrm{cfu} / \mathrm{ml}$, and $25 \mu \mathrm{l}$ of two-fold dilutions were mixed with $25 \mu$ l of rabbit erythrocytes ( $3 \%$ suspension) in polyvinyl microtitration plates. After incubation at $22^{\circ} \mathrm{C}$ for $1 \mathrm{~h}$, haemagglutinin (HA) activity was recorded as the highest dilution of bacterial suspension giving strong haemagglutination.

\section{Salt aggregation test $(S A T)$}

Bacterial suspensions in physiological saline were mixed with different concentrations of ammonium sulphate $(0.5-3.0 \mathrm{M})$ in $0.02 \mathrm{M}$ sodium phosphate buffer, $\mathrm{pH} 6.8$, on glass slides, and examined after $2 \mathrm{~min}$. The lowest concentration of ammonium sulphate that produced bacterial clumps (SAT value) was recorded to show the relative cell-surface hydrophobicity, lower SAT values corresponding to greater cell-surface hydrophobicity. ${ }^{4}$

\section{Congo-red binding to bacteria}

CF broth cultures were centrifuged, washed in phosphate-buffered saline (PBS), and re-centrifuged; then $3 \times 10^{10}$ bacteria were incubated for $10 \mathrm{~min}$ at room temperature in $3 \mathrm{ml}$ of PBS containing $50 \mu \mathrm{g}$ of Congo red. The bacteria were removed by centrifugation, and the Congo red remaining in the supernate was determined ${ }^{4}$ by measuring the absorbance at $480 \mathrm{~nm}$.

\section{Colonic epithelial cells (CECs) of guinea-pig}

Preparation of cell suspension. CECs were prepared by the method of Dean and Isaacson. ${ }^{5}$ The colon was excised from a 500-g adult guinea-pig. The external and internal surfaces were rinsed with cold $0.1 \mathrm{M}$ PBS, $\mathrm{pH} \mathrm{7.5}$, and kept in PBS at $4^{\circ} \mathrm{C}$ for $30 \mathrm{~min}$. The intestine was slit open and cleaned of any mucus and 
excreta, and the tissue was washed in PBS. Epithelium was removed by scraping with the blunt edge of a scalpel blade. Epithelial cells were collected by centrifugation at $200 \mathrm{~g}$ for $10 \mathrm{~min}$, washed three times in PBS and resuspended in PBS at a concentration of $10^{9} \mathrm{CECs} / \mathrm{ml}$. Cell density was determined by use of a haemocytometer and a Leitz Dialux 22 phase-contrast microscope. All the manipulations were performed at $4^{\circ} \mathrm{C}$.

Assay of shigella adhesion. Quantitation of the adhesion of radiolabelled shigella to CECs was performed essentially by the method of Sugarman and Donta. ${ }^{6}$ Bacteria were grown in $20 \mathrm{ml}$ of CF broth containing $1 \mu \mathrm{Ci}$ of $\mathrm{C}^{14}$ leucine for $18 \mathrm{~h}$ at $37^{\circ} \mathrm{C}$ with shaking; and $200 \mu \mathrm{l}$ of a bacterial suspension $\left(10^{11} \mathrm{cfu} / \mathrm{ml}\right)$ in KRT, washed three times in KRT, was incubated with an equal volume of CECs $\left(10^{9} / \mathrm{ml}\right)$ in a shaking water bath ( 60 horizontal strokes $/ \mathrm{min}$ ) for $1 \mathrm{~h}$ at $37^{\circ} \mathrm{C}$. After incubation, the mixture was filtered through a membrane filter of pore size $8 \mu \mathrm{m}$ (Millipore Corporation) fitted in a disc filter holder attached to a glass syringe. The filters were washed with $15 \mathrm{ml}$ of KRT to remove non-adhering bacteria and then dried for $18 \mathrm{~h}$ at $37^{\circ} \mathrm{C}$. Dry filters were then placed in ReadySolv HP (Beckman Instrument Inc., USA) and radioactivity $(\mathrm{dpm})$ of the adherent bacteria retained by the filter was assessed with a Beckman liquid scintillation counter LS1801. Adherence was expressed as a percentage of the radioactive count (dpm) of bacteria in the incubation-mixture, that was found in the radioactive count ( $\mathrm{dpm})$ of bacteria adhering to epithelial cells retained on the $8-\mu \mathrm{m}$ filter.

To observe the effect of monosaccharides, glycoproteins or enzymes on the adhesion, either the epithelial cells or the bacteria were treated with $200 \mu \mathrm{l}$ of reagent in $\mathrm{KRT}$ at $37^{\circ} \mathrm{C}$ for $1 \mathrm{~h}$ on a shaker water bath; concentrations of the reagents $(/ \mathrm{ml})$ were glucose $10 \mathrm{mg}$, mannose $10 \mathrm{mg}$, fucose $10 \mathrm{mg}, \mathrm{N}$-acetyl neuraminic acid $10 \mathrm{mg}, \mathrm{N}$-acetyl glucosamine $10 \mathrm{mg}, \mathrm{N}$ acetyl mannosamine $10 \mathrm{mg}$, fetuin $200 \mu \mathrm{g}$, thyroglobulin $200 \mu \mathrm{g}$, trypsin $10 \mathrm{mg}$, protease $10 \mathrm{mg}$, neuraminidase 5 units. The treated cells or bacteria were then washed and resuspended in KRT for adherence tests.

Appropriate controls without epithelial cells were included to measure background bacterial adherence to the filter alone, in the presence or absence of test reagents. Such background adherence never exceeded $0.025 \%$ of the test value $(100 \mathrm{dpm})$.

\section{Results}

Table I shows that all four strains adhered to guineapig CECs in vitro, though the strains of $S$. flexneri (especially strain ND22) adhered less well than those of $S$. dysenteriae type 1 . The high SAT values indicate that all the strains had a similar but low degree of hydrophobicity. Neither the SAT value nor the HA titre was related to the degree of adhesion; but, with these four strains, Congo-red binding showed some correlation with adhesive ability.

When bacteria were treated with fucose before mixing with CECs, a marked decrease in adherence was observed with all four strains (table II). After pretreatment with $\mathrm{N}$-acetyl mannosamine and thyroglobulin, only three strains showed marked inhibition of adherence. The inhibitory effect of $\mathrm{N}$-acetyl neuraminic acid was very weak with two strains but very strong with the other two (one of each species). Adherence of strain ND22 was inhibited only by fucose. Other monosaccharides and glycoproteins (glucose, mannose, $\mathrm{N}$-acetyl glucosamine and fetuin) had no effect on any strain. As with $\mathrm{N}$-acetyl neuraminic acid, pre-treatment with the three enzymes (neuraminidase, protease and trypsin) affected one strain of each species more strongly than the other.

Pre-treatment of the CECs with the same monosaccharides, glycoproteins and enzymes had no effect on the adhesion of any of the bacterial strains.

\section{Discussion}

Our observations suggest that, as with many other enteric bacteria, the adherence of $S$. dysenteriae type 1 and $S$. flexneri to guinea-pig CECs is mediated by an adhesin which binds to the receptor on the epithelial surface and involves sugar moieties. Fucose is probably the monosaccharide mainly involved in the

Table I. Correlation in four Shigella strains between CEC-adherence, haemagglutination, Congo-red binding and salt aggregation

\begin{tabular}{ll|lrcc}
\hline \multicolumn{1}{c|}{ Species } & $\begin{array}{c}\text { Strain } \\
\text { no. }\end{array}$ & $\begin{array}{c}\text { Mean (SD) } \\
\text { percentage } \\
\text { adherence* } \\
\text { to CECs }\end{array}$ & $\begin{array}{c}\text { HA } \\
\text { titre }\end{array}$ & $\begin{array}{c}\text { Congo-red } \\
\text { binding } \\
\mu \mathrm{g} / 10^{10} \\
\text { bacteria) }\end{array}$ & SAT ${ }^{\dagger}$ \\
\hline S. dysenteriae type 1 & 1609 & $40 \cdot 1(2 \cdot 2)$ & 512 & $6 \cdot 7$ & $2 \cdot 5$ \\
S. flexneri & PB60 & $31 \cdot 3(1 \cdot 1)$ & 0 & $6 \cdot 7$ & $2 \cdot 5$ \\
& IDBM330 & $23 \cdot 2(1 \cdot 3)$ & 128 & $5 \cdot 9$ & $2 \cdot 5$ \\
& ND22 & $13 \cdot 0(1 \cdot 5)$ & 0 & $4 \cdot 9$ & $2 \cdot 5$ \\
\hline
\end{tabular}

* From five experiments.

$\dagger$ Expressed as minimal molar concentration of ammonium sulphate that caused bacterial clumping. 
Table II. Effect, on bacterial adherence to CECs, of pre-treatment of bacteria with monosaccharides, glycoproteins and enzymes

\begin{tabular}{|c|c|c|c|c|c|c|c|c|}
\hline \multirow[b]{2}{*}{ Species } & \multirow[b]{2}{*}{$\begin{array}{l}\text { Strain } \\
\text { no. }\end{array}$} & \multicolumn{7}{|c|}{ Mean (SD) relative adherence* after treatment with } \\
\hline & & L-fucose & $\begin{array}{l}\mathrm{N} \text {-acetyl } \\
\text { neuraminic } \\
\text { acid }\end{array}$ & $\begin{array}{c}\mathrm{N} \text {-acetyl } \\
\text { mannosamine }\end{array}$ & thyroglobulin & neuraminidase & protease & trypsin \\
\hline $\begin{array}{l}\text { S. dysenteriae } \\
\text { type } 1 \\
\text { S. flexneri }\end{array}$ & $\begin{array}{l}1609 \\
\text { PB60 } \\
\text { IDBM330 } \\
\text { ND22 }\end{array}$ & $\begin{array}{l}55.0(2 \cdot 5) \\
62.4(2 \cdot 2) \\
66.5(2 \cdot 1) \\
39.6(3 \cdot 0)\end{array}$ & $\begin{array}{l}84 \cdot 8(2 \cdot 1) \\
35 \cdot 5(1 \cdot 2) \\
43 \cdot 6(2 \cdot 6) \\
95 \cdot 0(1 \cdot 7)\end{array}$ & $\begin{array}{l}48 \cdot 0(2 \cdot 7) \\
60 \cdot 6(1 \cdot 3) \\
60 \cdot 0(2 \cdot 6) \\
78 \cdot 6(2 \cdot 1)\end{array}$ & $\begin{array}{l}48 \cdot 5(2 \cdot 5) \\
48 \cdot 3(2 \cdot 3) \\
60 \cdot 8(1 \cdot 6) \\
75 \cdot 1(2 \cdot 3)\end{array}$ & $\begin{array}{l}91.1(2.4) \\
51.9(2.9) \\
55.0(2.3) \\
78.4(1.8)\end{array}$ & $\begin{array}{l}72 \cdot 4(2 \cdot 1) \\
54 \cdot 5(1 \cdot 3) \\
68 \cdot 8(1 \cdot 9) \\
75 \cdot 3(2 \cdot 6)\end{array}$ & $\begin{array}{l}79 \cdot 2(1.9) \\
56 \cdot 8(2 \cdot 7) \\
47 \cdot 0(1 \cdot 8) \\
70 \cdot 2(2 \cdot 2)\end{array}$ \\
\hline
\end{tabular}

* Relative adherence is expressed as a percentage of the adherence of untreated bacteria. The results are recorded as the mean (SD) of five experiments.

adherence of both Shigella spp. However, N-acetyl neuraminic acid and $\mathrm{N}$-acetyl mannosamine were effective inhibitors with some of the strains only; it is possible that more than one adhesin molecule, with different sugar specificities in different strains, are involved in the adherence process. Izhar et al. ${ }^{7}$ have suggested fucose to be the important monosaccharide in the adherence of $S$. flexneri to guinea-pig intestinal cells, although they obtained the effect by sugarpre-treatment of the epithelial cells rather than the bacteria. A fucose-sensitive adhesin has been suggested for Vibrio cholerae also ${ }^{3}$. Unlike the adhesins of

\section{References}

1. Guhathakurta B, Sasmal D, Sen D, Datta A. Haemagglutination of Shigella dysenteriae I and Shigella flexneri. Med Sci Res 1988; 16: 77-78.

2. Evans DJ, Evans DG, DuPont HL. Hemagglutination patterns of enterotoxigenic and enteropathogenic Escherichia coli determined with human, bovine, chicken, and guinea-pig erythrocytes in the presence and absence of mannose. Infect Immun 1979; 23: 336-346.

3. Jones GW, Abrams GD, Freter R. Adhesive properties of Vibrio cholerae: adhesion to isolated rabbit brush border membranes and hemagglutinating activity. Infect Immun 1976; 14: 232-239.
Escherichia coli and $V$. cholerae, the adhesin of $S$. dysenteriae type 1 and $S$. flexneri probably is not an HA because adhesion occurred with strains showing no haemagglutination.

Qadri et al. ${ }^{4}$ observed that Congo-red binding was related to the virulence of Shigella spp. Our observation that Congo-red uptake correlated with the adhesiveness of strains supports their contention.

The inhibitory effect of pre-treatment with enzymes, on adhesion of bacteria to CECs, may possibly be due to alteration of the binding sites or hydrophobicity and net surface charge of the bacteria.

4. Qadri F, Hossain SA, Čižnár I et al. Congo red binding and salt aggregation as indicators of virulence in Shigella species. $J$ Clin Microbiol 1988; 26: 1343-1348.

5. Dean EA, Isaacson RE. In vitro adhesion of piliated Escherichia coli to small intestinal villous epithelial cells from rabbits and the identification of a soluble $987 \mathrm{P}$ pilus receptorcontaining fraction. Infect Immun 1982; 36: 1192-1198.

6. Sugarman B, Donta ST. Adherence of Enterobacteriaceae to human buccal cells. J Med Microbiol 1979; 12: 373-378.

7. Izhar M, Nuchamowitz Y, Mirelman D. Adherence of Shigella flexneri to guinea pig intestinal cells is mediated by a mucosal adhesin. Infect Immun 1982; 35: 1110-1118. 